International Journal of Social Science And Human Research

ISSN(print): 2644-0679, ISSN(online): 2644-0695

Volume 04 Issue 10 October 2021

DOI: 10.47191/ijsshr/v4-i10-39, Impact factor-5.586

Page No: 2944-2951

\title{
Humanization and Health: Assays on the Alterity in Hands-On Therapies
}

\section{Joàovitaliano De Carvalho Rocha}

\begin{abstract}
This study represents a theoretical-philosophical essay on the practice of care by participants of therapies by laying on of hands present in our professional daily life and is based on the concept of alterity developed by Emmanuel Lévinas, evidencing the manifestation of alterity in the art of caring for others. , which represents the humanization that arises from the relationship and dialogue between the therapist and the beneficiary. In this practice of donation, dialogue is established and care is carried out, expressing the living thought of beneficence and the humanization process.
\end{abstract}

\section{INTRODUCTION}

This study makes reference to the thinking of the philosopher Emmanuel Lévinas, born on November 30 , 1906 in Lithuania, a country in which he stayed until completing his secondary studies. Emigrating to France, he later carried out his philosophical studies within the traditions of French and German philosophy, more particularly, the phenomenological tradition of Edmund Husserl and Martin Heidegger. In his career as an intellectual and educator, he held the chair of philosophy at the Universities of Poitiers, Paris-Nanterre and the Sorbone. It suffered the consequences of the holocaust, but maintained its relationship with Judaism and religious texts, more particularly with the Bible and Talmud. Lévinas's philosophical work appears as systematic works and articles diversified in their subject, being marked by a deep sensitivity to human problems, which, in most cases, does not find a place in the works of the so-called great philosophers, nor in the great systems that shape the history of philosophy (SOUZA, 1999, p.45). Lévinas left an important legacy for philosophy composed of 27 works ranging from the first, which was the publication of his doctoral thesis: Theory of Intuition in Husserl's Phenomenology in 1930, to the last Nouvelles Lectures Talmudiques in 1996. His role in the 20th century brought debates about the need and importance of ethics in our lives (MORGAN, 2011, p.13).

Addressing Emmanuel Lévinas' philosophy is an undertaking full of challenges and the reading of his work shows that he is facing the demanding Other. In this way, a reading alone does not allow one to perceive the novelty of their propositions. His way of philosophizing points to another way of being, to a way of reading, which is a request and testimony, awakening a feeling of hospitality and welcome from the Other who comes to me from a distance and, therefore, is not on the same level as me. . From the knowledge of the activities carried out by the participants of manual therapies and the way they face those who seek them, we intend to bring to the knowledge of the academic world, through this research, the notion of otherness experienced by this group that extends the service not aiming at the domain, but rather the responsibility that should occur in inter-human relationships enabling the emergence of peace and health with the Other, so necessary in our midst. The fraternal care group enables a thought capable of welcoming the Other in its simplicity, not trying to reduce it to a simple identity. Lévinas is an author who puts the reader in a state of suspension of knowledge linked to the meshes of formal logic (MELO, 2003, p.21). Lévinas did not develop a philosophy of religion or a social and political philosophy, but his writings lead the reader to discover that his immediate reference works as a bridge connecting different philosophical systems.

Lévinas places ethics as the first philosophy and, having suffered the Nazi horror, he sought to concretize in his philosophical system a thought that manifested the meaning of alterity and, for this understanding, he sought an alternative whose proposal was to live ethics in living with others and, thus reaching otherness, a quality that reflects a more human condition. After returning from long hours of forced labor, he recognized the inexistence of otherness at the time he was living, which led him to think that what gives meaning to entities in the world would be in an impersonality, arid and neutral that could only be overcome in being for the other, as an ethical moment of respect for otherness (MANCE, 1994).

Otherness represents an effort of restitution and ontological primacy to the Other, often denied throughout the history of philosophy in the Western world in which the presence of the Other, when in a face to face, leads us to rethink the privileges of the self and, when it projects in the Other's thought with the same ethical requirement, it makes absolute otherness emerge from an exteriority that does not deviate or constitute itself in any other instance, but in itself. In the relationship with the other, a moral conscience of the subjects emerges, in which the Other is, then, my limit, preventing me from continuing to invade it. The relationship of the same 


\section{Humanization and Health: Assays on the Alterity in Hands-On Therapies}

with the Other occurs through the language that, through speaking, supposes a possibility of breaking and beginning, as the desire for exteriority that transcends the being moves in discourse and not in knowledge.

\subsection{Etymology and Concept of Alterity}

The word Alterity derives from the Latin "alter" which means to be other or to constitute oneself as or for the Other, was adopted by Lévinas in an attempt to develop the sensitivity of responsibility towards the Other, constituting an effort to restore their citizenship and primacy. All people who have the responsibility to provide care in the field of health are involved and are constantly called to this action, hence it is stated that the inclusion of otherness as an ethical criterion confirms the human values that will serve as a reference for professional behavior (SADALA, 1999).

The Alterity proposed by Emanuel Lévinas shows that the nonsense of vast frustrated enterprises in which politics and technique result in the denial of the projects that guide them, thus showing the inconsistency of the man who became a victim of his works (LÉVINAS, 2009, p.71). When being means to exist, in the way nature does, then everything that is refractory to the categories and mode of existence of nature, as such, has no objectivity and will be, a priori and inevitably reduced to something natural. The characteristics of such objects will be reduced to purely subjective phenomena which, with their multifaceted structure, are the products of natural causality. Despite manifesting rationality, a condition inherent to human beings, man opted for the construction of a technical, capitalist and inhumane society, in which the ethical value of being human was relegated to the last position, being forced to rethink his plans for the future, especially, because the wounds of your mistakes will not heal in the short term.

In Lévinas' philosophy there is no possibility of thinking about alterity without an analysis of the Face and it is from this concept that the essence of the human being is expressed in a concrete way in which the Face is something of capital importance in the infinite condition of the human being:

"The Other that manifests itself in the Face somehow permeates its own plastic essence, as a being who would open

the window in which its figure was already drawn. Its presence consists of undressing in the way it already manifested itself and its manifestation represents a surplus over the inevitable paralysis of the manifestation". This is exactly what is described by the formula given by Lévinas in the Face speaks (LÉVINAS, 2009, p.51).

Lévinas' considerations, placing ethics as the first philosophy rekindled the issue of humanism when he proposed a morality capable of protecting man against himself. In fact, it was not humanism that failed, but the interpretations that were made of it, in the past, in which the question of the degree of consciousness of man in relation to his conception of otherness was not addressed. Haddock (2006) asserts that alterity is not just a quality of the Other, but its instance, the truth of its being, which makes it very easy to remain in the community and in fraternity. The greatest degree of difficulty is in sharing the same space, sharing with the difference and living the relationship between you and me, deeply, as seen in the laying on of hands therapies.

\subsection{The Paths of Alterity from the Face of the Other}

According to Lévinas' reflections, the possibility of looking face to face and in a true way without any hidden interests or evil pretensions, the vision of the Face of the other, meaning the ultimatum to a tradition of thought, in which the constitution of meaning is privileged. In the face to face with the Other, moral conscience is created, a relationship of alterity, because the therapist leaves himself through the call of the Other who appears different, committed to his health, demanding from him a preparation for quality care. For Lévinas, the Face is something of great importance given the infinite relationship of human beings. The Other that manifests itself in the Face goes beyond, in some way, its own plastic essence, as being that would open the window of its figure, however, it was already drawn. His presence consists of undressing in the way that, in one way or another, was already manifested. And this reality is described by the expression: the Face speaks (LÉVINAS, 2009, p.51).

Throughout his speech, Lévinas expresses that the first manifestation of the human being is in the Face and this is an important reason for us to receive the Other with our best expression. Lévinas asserts that the Self in the presence of the Other becomes extremely responsible (LÉVINAS, 2009, p.53).

Lévinas considers that there is a separation between the self and the Other, an exteriority, since I cannot know it based on categories, rules and knowledge existing in me. It is necessary to realize that the idea of the infinite, therefore, does not come from me or from a need of the self that accurately assesses its emptiness. Understand that the movement starts from the thought and not the thinker. It is the only knowledge that presents this inversion in which the idea of the infinite is revealed in the broadest sense of the term (LÉVINAS, 1980).

When we think about human relationships, we always need to keep in mind that the one who arrives at the meeting is absolutely different in relation to me. The Other in the face-to-face relationship is also a revelation to oneself. The ethical relationship with the other is language, face to face, in short, it is not thematizing the Other in my world, but in the egoism of my communication, sharing my world with the Other. Language is donation and donation is the first ethical gesture (COSTA, 2000, p.230).

For Lévinas, considering the face is, above all, not fitting it into a relationship of knowledge. The way the other presents himself beyond the idea of the other in me actually calls him Face. This way does not consist in appearing as a theme in my eyes, in exposing itself as a set of qualities that form an image (LÉVINAS, 1980, p.37). 


\section{Humanization and Health: Assays on the Alterity in Hands-On Therapies}

The Face is presented in different ways in the environment where the experience happens naturally. Face and happiness, Face and reason, Face and sensitivity that must always manifest itself spontaneously. When someone asks me for help, I feel responsible for trying to meet the request, and this responsibility with the Other is solely up to me. The Face can have its own meaning, and cannot be transferred to a third party, therefore, the reading will be made from the expression taking proportions of its character (LEVINAS, 1980, p.38).

When you have an idea of infinity, you perceive the idea of the perfect, a model that leads us to recognize our own imperfection. Therefore, it is a mistake to disregard the other, judging him inferior for not belonging to our social group. It is important to remember that the infinite does not stop us as a force that puts mine in check, on the contrary, it questions all the naive right of my powers, my glorious spontaneity of being alive, of the force that moves me (LÉVINAS, 1980, p. 230).

\subsection{The Encounter with Alterity and the True Dimension of Humanism}

Lévinas' thinking opened the door to a new path and a new way of understanding the relationship of human beings. From a new perspective, different paths emerge, through which new proposals are developed on how to experience ethics with others, and thus reach otherness, allowing to glimpse in their thinking other mechanisms to improve education by providing a more humane formation (LÉVINAS, 2002, p.211). Based on this vision, Lévinas proposes to awaken in man the sensitivity of his peers by focusing on the face of each person, a moment in which he learns to be more human, thereby promoting the true otherness represented by welcoming the Other.

The construction of a fairer, humane, solidary and fraternal society characterizes Alterity, which is seen as the approach well beyond the representation underlined in the being and in the presence that representation gives it, beyond its ontological contingency (LÉVINAS, 2002, p. 212). Aware of the consequences of war in the life of humanity, Lévinas proposes the revaluation of the human ethical sense and respect for differences. When looking at another person, one should keep a distance, not out of fear, coldness or fear, but out of respect for what the person is and represents. His invitation extends to the other, recognizing their importance and starts the formation of a society whose ideals seek to achieve humanism and pacifism (HADDOCK, 2006). The desire for the Other goes far beyond the interest, to which society is linked, and about this Lévinas (2009, p.49) asserts that our role is not to complete or add to the other, but simply to have the responsibility to assume the Other, regardless of who it is. In the therapies by laying on of hands, hospitality is offered to the other even without knowing their name, the main interest being the intention to provide them with any benefit, regardless of presentation. The name is not asked, nor what he should be called, he is just tenderly directed, placing him seated or lying down to receive the laying on of hands.

In this exchange, although silent, hospitality begins with the reception of the Other in a complete erasure of the private information that is not of interest in this encounter. The therapist calls him or not, by name, when hospitality is established for this subject, one offering welcome to the Other who, in life, is momentarily without an address or support, thus not offering a refusal to the one who put out your hand. The hospitality offered to those who arrive anonymously with no name and no social status becomes this type of treatment, unconditional. The feeling of those seeking care varies greatly due to entering an unknown place, in which the emotion felt is almost always that of an indefinable restlessness that gradually disappears, when the process of familiarization with the unknown takes place, freeing the caring guy. Familiarization will appear soon after the impact of the encounter with the unknown, mainly through the approach of the Other. Lévinas encourages us to think about the relationship with the Other not through an abstract thought, but through the relationship that takes place with the human Other, without mask or distance that prevents the visualization of the Face.

Contemporary philosophy is complete in the multiplicity of cultural meanings and in the endless game of art, which is one of the reasons that human beings have difficulty in surrendering to Otherness, with no rapport with the Other who remains indifferent in their relationships (LÉVINAS, 2009, p.46). It is from the condition of emptying oneself in front of the moment face to face that the human being glimpses the true dimension of humanism: It is the desire of the other, that we live in the simplest social experience considered a fundamental movement, the pure elan, the absolute orientation, the totality, the true meaning of life (LÉVINAS, 2009, p.49).

The humanization theme has been arousing increasing interest among professionals from different areas of knowledge. Humanization can be understood as the act or action of making relationships human, that is, taking into account everything that is related to man or his own. In the case of the influence of the holistic view on the humanization of therapies by laying on of hands, it is about the development of a view of the human being inserted in the biopsychosocial context, as a singular being who brings with him a life story impregnated with cultural values experiencing a moment in which, normally, they are weakened by their emotional or health problem, causing the individual to withdraw from their daily lives and start to obey institutional rules (LEITE and STRONG, 2006, p.204). The holistic view can be defined as the view of a given phenomenon as a whole, that is, it takes into account all the factors that can influence the observed phenomenon.

To humanize is to adopt a practice in which therapists and users consider the set of physical, subjective and social aspects that make up health care. Humanizing, therefore, refers to the possibility of assuming an ethical posture of respect for the other, welcoming the unknown and recognizing limits (LEITE \& STRONG, 2006, p.207). 


\section{Humanization and Health: Assays on the Alterity in Hands-On Therapies}

\subsection{The Ethics of Otherness and Responsibility to Others}

Responsibility towards others does not only correspond to legal standards, it forces me to go beyond all contracts. It charges me with the not-present, the immemorial. Between me and the Other opens up a difference that no unity of transcendental perception could recover. The act of welcoming the face has been associated with the conditions of the meeting itself without imposing its own interests or wishes (LÉVINAS, 2002, p.105).

It is in the search to take responsibility for the other that is expressed in the Face, and it is up to each one to become human with the other. The sensitivity of the participants in the laying on of hands therapies constitutes the best way for a better relationship and understanding of the manifestation of the otherness that exists within the human being. A human being capable of offering shelter by sensitively welcoming the Other, from the first contact, as stated by Costa (2000, p.167):

"It is the sensitivity of one to the Other, which allows one to receive the Other. A sensitive and singular human

being who sensitively receives the Other, like tasty food that he feeds, clothes that warm up, water that quenches thirst or a roof that covers, etc. In this dimension of sensitivity, which would be the best path to a better relationship and understanding, the human being is open to the Other, who needs his attention."

In the scope of Alterity ethics, the human being becomes totally welcoming of the Other who presents himself to the Self, questioning responsibility. The dimension of alterity thought by Lévinas provokes an interior change, idealizing a society with better conditions to live. Supported by the welcoming subjectivity of the Face, the law will not be reduced to a rationality through procedures that create codes, norms of responsibility, but will become a promoter of peace and good for all (LÉVINAS, 2005, p.294).

In Lévinas' considerations (2002, p.105) there is a separation between the self and the Other, an exteriority, since I cannot know it from the categories, rules and knowledge existing in me. No matter how much you research and know your origin, your culture, your life, the other in the face-to-face relationship is a stranger, an unknown. The act of welcoming the face has been associated with the conditions of the encounter itself when the ego welcomes without occupying the foreground, without elaborating rules or laws, without imposing its own interests or wills.

The crisis that Lévinas denounces does not result from the constant ruptures in the structures of thought and social values, but represents the existential coldness to which man has accommodated himself, forgetting the equality in humanity of his fellow man. This crisis that is not restricted to theoretical-academic discussions, but that reach the annulment of the man himself who sees his existence disrespected by his fellow man. The experience is shown as a result of the life of each person, of each citizen who, after participating in this experience, had by experience the conjuncture of elements that mean from the world and from the position of the one who looks (LÉVINAS, 1993, p.24).

Responsibility towards others does not only correspond to legal standards, it forces me to go beyond all contracts. It charges me with the not-present, the immemorial. Between me and the other there is a gap that no unity of transcendental perception could recover. Experience that my responsibility for others is precisely the non-difference of this difference, that is, the proximity of the other (LÉVINAS, 2002, p.105).

\subsection{The Ethics of Alterity in the Process of Meaning}

Rational justice is restricted to processes and cannot match the goodness that calls and animates it, but when it arises from the infinite resources of the singular self, goodness, responding without reasons and without reservation to the appeal of the face, knows how to find ways to go. to this face that suffers (LÉVINAS, 2005, p.295). Meaning is presented as prior to data perception, precisely because it develops throughout the formative and constitutive process of the person or group, thus, meaning precedes the data and clears them (LÉVINAS, 1993, p.25). It is understood that the process of meaning can enable the individual in an adequate, or unsatisfactorily incomplete, way to critically interpret the data, the social facts that are presented to their perception. Therefore, this process is extremely important for the evaluative understanding that the individual weaves about the facts of life, including the dimension of good and evil that can be done to the other.

Self-transcendence marks the fundamental anthropological fact that man's existence always refers to something other than himself to something or someone, that is, to a goal to be achieved or to an existence of someone else he meets. Frankl (2005, p.20) asserts that man only becomes a man and is only completely himself when he is absorbed by dedication to a task, when he forgets himself in the service of a cause or in the love of a person. a fact observed from the contact with people who assume responsibility for the Other through the practice of laying on of hands. The questioning of the meaning of transcendence and the relationship to transcendence, a relationship in which the self can find the path to ethics, as the Other is a striking feature in Lévinas' trajectory.

Self-transcendence, in Frankl's opinion, (2005, p.29) is the only way that enables the realization of human beings because he forgets himself and concentrates on thoughts further on, forgetting his own life and dedicating it. to others even if they do not belong to the same family. The self-transcendence of human existence consists in the primordial fact that it always points beyond itself, towards someone or something, a moment when it is possible to realize itself, overcoming its physical, psychological, fears, prejudices or limits criticism.

Self-transcendence is a characteristic of human beings that allows them to leave themselves to find a meaning for their existence. When he immerses himself in self-transcendence, human beings are able to forget about themselves and give themselves, going in 


\section{Humanization and Health: Assays on the Alterity in Hands-On Therapies}

search of a meaning to make them happy. This movement of leaving oneself enables men to contemplate the beauty of life, finding meaning in the delivery and donation to the Other (FRANKL, 2005, p.113).

\subsection{The Meaning of God and the Relationship between the Subject and the World}

The meaning of God is the ultimate instance of Levinasian thought. The evasion carried out, the movement back to the anteriority of the thematization of God only takes place in an ethical relationship. In his work De Dieu que Vient al Idée, Lévinas makes clear his conception of God, the ultimate instance of ethics and the infinite, intending to overcome the logical wear of language and speech, ensuring the importance of ethics as the only testimony capable of indicating that only in love to the other one can find the meaning of God. The idea of God emerges in the Face of the Other, image of the infinite. Only in the relationship with the Other, that this idea is manifested in the appeal of the other and in the response given by the subject, does love become truth and witness to revelation. The love of neighbor, the desire for the good of others in the first place, the practice of justice, the search for peace, are ways of meaning the divine. God is present in the idea of welcoming the Other, in the concrete experience of love among men (MELO, 2003, p.32).

In resuming the relationship that Lévinas establishes between the subject and the world, it is possible to note that intentionality is one of the keys to its understanding and presents the world as something that is given and that does not come from the subject, but rather received. The subject's relationship in the world perfectly corresponds to desire and satisfaction. Being in the world and knowing oneself in the world is to live this knot of relationships in which subject and world are united by the close ties of an identification that would not mean a representation or an adaptation of what the subject thinks about the object. In this way it becomes evident that the transcendentality of consciousness is, above all, a concrete fact, immediately linked to the concrete reality of the world. The event of intentional consciousness is, at the same time, transcendence and immanence, and this is a way out that justifies the relationship between object donation and subjectivity (MELO, 2003, p.47).

The ethical relationship or the new order of thinking is the inversion of the totalitarian order of reason and the rescue of the Other man's humanism. Lévinas considers that philosophy becomes the wisdom of love, therefore, older than the concept or revelation, an incomprehensible mystery. The otherness of the other is the only way to immerse yourself in the mystery of the creature and the Creator, and redemption takes place in the manifestation of the ethical relationship. In man's love for the Other, the love of God is revealed, and the new way of being of humanism is unveiled. This philosophical proposal by Lévinas proves to be critical of the self-proclaimed humanist wisdoms.

Human beings live in the world and in its corporeality, united to objects and all material or immaterial things, as they depend on them for their survival. It is made up of matter, psyche and spirit in a transcendent dimension. These three components, united in the same being, form its complex constitution. Intertwined with these three elements are emotions, conflicts and anxieties, as what is desired or needed is not always morally accepted by man or society.

The ethics of alterity that Lévinas proclaims as an event of transcendence is true religion being the most sublime manifestation of the acceptance of the Other. The religion of the Other is a return to metaphysics, that is, another way of thinking about God based on testimony, hermeneutics of solicitation and solicitude, and a humanism of the other man. Levinasian humanism consists, therefore, in the practice of love and justice. Ethics, as a witness to revelation, awaits man's response and the response that God expects from man is his love for his neighbor and in this way of loving is found the path that leads man to eternity. Man's love for his neighbor is the effectiveness of redemption (MELO, 2003, p.22).

Living in contemporaneity, a period in which uncertainty and constant transformations are the preponderant mark, the human being goes through a disbelief in relation to collective happiness, together with which individual achievement is sought, without major ethical commitments, emptying the meaning of existence.

Bastiani $(2008$, p.10) asserts that contemporaneity brings with it a great paradox in which, on the one hand, we witness a gigantic technological progress at the service of life and human well-being, on the other hand, it can be glimpsed, without much effort , countless forms of inhumanity committed against human beings and the environment. The rationality of the human creature, with all the desire for change and growth, generated a control of everything and everyone, leading humanity to an unprecedented crisis. In fact, the 20th century, despite the false promise of improving health and increasing food production at a global level, ended up reducing the Other to the condition of not being absolute since the beginning of the century.

Gomes (2008, p.25) considers the contemporary human being as fragile and often subjugated by their own production, and that, at each step in scientific and technological advancement, they become more dependent on their creation. This fragility and dependence of man in contemporaneity is opposed to what was expected to be achieved with the proclaimed rationality and humanism. For Lévinas (1993, p.82) the crisis of humanism in the contemporary world has, without a doubt, its source in the experience of human inefficiency, which is called into question by the very abundance of our means of acting and by the extension of our ambitions. The human being with his rational and humanist model of contemporary society has made a big mistake in understanding a world closed in itself, in which he tries to impose himself on the other by presenting a model of competitiveness that gives more value to material things than to spiritual things.

The advancement of technology through cell phones has promoted a true individualization, making people move away from the dialogue or even from checking the other's face expression. Lévinas (2009) expresses concern with the ethical relationship, of which 


\section{Humanization and Health: Assays on the Alterity in Hands-On Therapies}

humanity regardless of age has become a victim, because when looking at the other person, one should not keep a look of coldness, fear or fear, but a distance of respect for what the person is and represents in the space where they live.

The direct consequence of this technological advance has been forming in society a subject that is enclosed in itself, with the fixed idea of the desire for power and the production of consumption, and this positioning of humanity led Lévinas to critique the ancient wisdom of those who proclaimed themselves humanists. The most absurd fruit of the totalitarianism of this concept was presented in Realpolitik and all the consequences that resulted in wars, deaths, political and religious persecutions, exclusion of orphans, widows and foreigners. Western rationalist systems failed because they transformed man into a being submitted to the concept and stuck to the limits of reason and its absurdity (MELO, 2003, p.21).

Lévinas considers that there is in human beings a degree of awareness in relation to Alterity, even if they do not know the meaning of the word. In fact, not all human beings, regardless of age, often go through life without being aware of it. Facing the changes in capitalist society, the human being does not mature the idea of sharing the same space and, therefore, cannot reach the depth of the relationship with the other. When thinking about and analyzing the philosophy of ancient ethics that was based on Western ontology, it is possible to understand why Lévinas criticized this ancient thought, which, compared to our contemporary society, has much in common (LÉVINAS, 2009).

Lévinas destroys the conception of the creation of totalitarian Being as presented by ontology, closed in on itself, suggesting that man finds his true root in ethics that leads him to understand the responsibility of the Self towards the Other, thus constituting the essence of human life. Lévinas assures that the best way to live in society is to mature this dimension that every human being has of sensitivity and responsibility for others. This transformation process considers Costa \& Caetano (2014, p.208) to begin with the presentation of the Face that speaks, hence, for Lévinas, as society continues to elevate the sense of Being, as a priority in its organization, as the Western ontology presents, the ethics of alterity will not happen, as there will be no place for the care of others and responsibility as the Other.

In the relationship with the Other, the subjects' moral conscience is created in which the Other represents my limit. The relationship with the Other takes place through language and speaking presupposes a possibility of breaking and beginning, as the desire for exteriority that transcends being takes place in discourse and not in knowledge. Ethical awareness can never do without the encounter of the voice that challenges, from its exteriority, with the one who listens and the otherness is constituted in this space that we call dialogic, because the different Other calls me to new behaviors and attitudes. The ethics of alterity constitutes a possibility of rescuing the sensitivity for welcoming the other, dual and infinite responsibility of the subjects involved in face-to-face will lead to the rescue of humanism (HAMES, 2008, p.251).

\subsection{The Ethics of Alterity in the Laying on of Hands Therapies}

The laying on of hands therapists involved in everyday practices often find themselves involved in difficult situations that involve health in general. They are often sought after by people who have lost confidence in allopathic medicine and risk a treatment to minimize their suffering through a technique using energy that does not require physical touch or the ingestion of medicinal substances. Without abandoning hope in front of the Other who asks for help, they promise nothing, but offer the warmth of words and solidarity in the most difficult moments, thus expressing alterity regardless of adverse conditions that may arise unexpectedly. Often without the money for the ticket, they put themselves in the place of the other person who will receive help in the form of care, without abandoning their commitment. What do they want in return, if not, the simple satisfaction of seeing the Other happy and recovering from the evils that afflict him?

The fraternal care groups in a community present woman as the main protagonists of the tasks that should be developed throughout the sessions, because of their sensitivity and devotion, characterizing the view that they must be integrated as an active participant in the care of the Other and of your own care. For Lévinas, the alterity of the feminine does not consist in an externality of the object, nor is it made up of an opposition of wills. Nunes (1993, p.171) considers that female sensibility does not see the Other as a threat, much less as someone who invades her life. The mystery of the feminine is found in her way of being and in her ability to love without distinction and this transforms her into a power constituting her otherness. In these groups the figure of the woman resembles the devoted figure of the mother who goes out to turn on the lights on all the family members entrusted to her, the number of women is always much greater than the male group, so they assume the responsibilities for the organization and cleaning of the environment, screening of those who will receive treatment, organization and supply of the kitchen providing breakfast for all participants and some visitors who came from far away, organization and cleaning of the service rooms, among other tasks.

It is in the face to face with the other that therapists, by laying on of hands, create their moral conscience, a moment when they leave themselves to meet the other who needs support and care, but who demands from the professional the necessary conditions for preparation so that there is an exchange of mutual trust beyond the physical body that allows its involvement, which allows the involvement in the relationship, facilitating the expression of conscience, affection and subjectivity, representing the necessary condition for the expression of the otherness of those who are involved. When we remove the otherness from the relationship between the therapist and the subject he serves, the harmonious relationship and dialogue are not established and care is not effective due to lack of harmony between them and because it is a non-symmetrical relationship (WALDOW, 1998). 


\section{Humanization and Health: Assays on the Alterity in Hands-On Therapies}

Humanized relationships in health happen from the meeting between two people, a moment in which the look at the subjects involved in the care process is broadened, especially in relation to those who need care, as it will not be limited to their biological body, the which seems to be the presupposition of humanization. The biggest challenge for the success of the service is to answer who is this other? What are its dimensions? How should a humanized relationship with him be established? It is necessary to be clear about how and where the other is located and how to direct humanized therapeutic actions with the person who needs help (ALMEIDA, 2012, p.400).

In the face-to-face or face-to-face relationship, therapists by laying on of hands need to allow the transparency of the face in front of the people who face it, which will characterize the construction of a new model of health care, whose practice takes place in a horizontal relationship, through which both the therapist and the patient need to give up something so that ethical care can be established. Stripping the condition of authority allows alterity to manifest itself in the relational context when it opens to hear the voice of the other, a moment when it will recognize the face and be recognized by it, establishing a relationship of authenticity, an effective care rescuing the professional pleasure of renewing itself and being with it in a continuous becoming.

The experience of alterity will allow us to overcome the abstract and individualistic view of personalism, rescuing the real and concrete subject to ethics and allowing him to live and reframe care in the current unequal context of health care, enabling a review of the humanistic precepts that constitute this action, in order to enable those involved in the meeting, therapist and patient, to develop a critical awareness from a dialogical relationship, through which both contemplate and are contemplated. The subject who defines himself/herself by caring for himself places the desire of the other, to which the Self is not a complement, because this Other is beyond what he may lack or satisfy (HAMES, 2008).

\section{CONCLUDING REFLECTIONS}

The ethics of alterity for Lévinas brings out a new conception of humanism in which the relationship with the alterity of the Other opens up the possibility for understanding the subjectivity of the individual. The centrality of the relationship with otherness is defined as a status, as a way of being of subjectivity, as sociality, as thought, as religion, as humanism that points to the original meaning of being and its relationship with the other. Lévinas considers the Other as the way of truth, the modality of being, the neighbor, the opening to the infinite. The traits of Alterity are experienced throughout fraternal care in therapy groups through the imposition of hands from which it is possible to attest to the articulation of some elements, such as ethics and humanization. The ethics of alterity can be glimpsed when the therapist visualizes the Face of those who will be assisted and allows their face to be visualized. The Alterity of the Face allowed Lévinas to insert in his speech a touch of solidarity with the despised faces of the world. Transcendence as an overcoming capacity enables the development of potentialities that make human beings capable of engaging in significant projects, which put them in contact with their Self and with the reality of those around them. Responsibility for the other is the basis of the statute of a morality that is guided by the desire for the infinite, for the Good beyond being, evidencing the authenticity of the virtue that consists in serving and obeying the other, as Totally Other.

The humanization of health care is represented by the relationship between health professionals and patients, evidencing the individual's uniqueness. With this humanism that comes from the other man, the human relationship proposed by Lévinas privileges the otherness of the neighbor, which is of fundamental importance for fraternal care, whatever the technique used, whose purpose is to take care of the concrete Other. Therefore, the absolute otherness supported by the face presents itself as a plausible possibility for the starting point of humanization.

\section{REFERENCES}

1) ALMEIDA, D Vieira de. Alteridade: ponto de partida da humanização dos cuidados em saúde? Revista Baiana de Enfermagem, Salvador, v.26, n.1, jan/abr. 2012. pp.399-407.

2) BASTIANI, Marcelo De. O Sentido do Humano como Responsabilidade pelo Outro no Pensamento de Lévinas. Dissertação. Porto Alegre. 2008. 86p.

3) COSTA, Márcio Luís. Lévinas: uma introdução. Petrópolis. Rio de Janeiro. Vozes. 2000. 239p.

4) COSTA, Juliano Xavier da silva. CAETANO, Renato Fernandes. A Concepção de Alteridade em Lévinas: Caminhos para uma Formação mais Humana no Mundo Contemporâneo. Revista Eletrônica Igarapé. n. 03, maio. 2014, pp.195-210.

5) FRANKL, Victor. Um sentido para a vida: psicoterapia e humanismo. Aparecida Santuário. Ideias e Letras. São Paulo. 11ed. 2005. 176p.

6) GOMES, Carla Silene C. Lévinas e o outro: a ética da alteridade como fundamento da justiça. Dissertação (Mestrado). Pontifícia Universidade Católica do Rio de Janeiro. RJ. 2008. 90p.

7) HADDOCK L, Rafael. Da existência ao Infinito: Ensaios sobre Emmanuel Lévinas. São Paulo. Editora PucRio. 2006. $166 \mathrm{p}$.

8) HAMES, Maria de Lourdes Campos. CARRARO, Telma Elisa. RAMOS, Flavia Regina. TOLL, Adriana Dutra. A alteridade como critério para cuidar e educar nutrizes: reflexões filosóficas da prática. Ver Bras Enferm. MarAbr.2008; 61(2):249-53. 


\section{Humanization and Health: Assays on the Alterity in Hands-On Therapies}

9) LEITE, Telma Alves de Almeida Fernandes. STRONG, Maria Isabel. A influência da visão holístic no processo de humanização hospitalar. O mundo da saúde São Paulo. 2006, abr/jun, 30(2):203-214.

10) LÉVINAS, Emmanuel. Entre nós. Ensaios sobre alteridade. Tradução de Stefano Pivatto (Coord) $2^{a}$ ed. Vozes. Petrópolis. RJ. 2005. 300p.

11) LÉVINAS, Emmanuel. De outro modo que ser o más Allá de La esencia. 4.ed.. Ediciones Sígueme. Salamanca. 2002. $257 \mathrm{p}$.

12) LÉVINAS, Emmanuel. Totalidade e Infinito: ensaio sobre a exterioridade. Tradução: José Pinto Ribeiro. Edições 70. Lisboa. 1980. 312p.

13) LÉVINAS, Emmanuel. Humanismo do outro homem. Trad.:Pergentino S Pivatto (Coord). Petrópolis:Vozes. 1993. 131p.

14) LÉVINAS, Emmanuel. Entre Nós. Ensaios sobre a Alteridade. Tradução de Pergentino Pivatto et al. (Coord). 4.ed. Petrópolis.Vozes. 2009. 306p.

15) MANCE, E A. Emmanuel Lévinas e a alteridade. Rev Filos, 1994.7(8):23-30.

16) MELO, Nélio Vieira de. A Ética da Alteridade em Emmanuel Lévinas. EdipucRS. Porto Alegre. RS. 2003. 311p.

17) MORGAN, Michael L. The Cambridge Introduction to Emmanuel Levinas. Cambridge University Press. 2011. 271p.

18) NUNES, Etelvina. O outro e o rosto. Problemas da alteridade em Emmanuel Lévinas. Braga: Publicações da Faculdade de Filosofia da UCP. 1993.

19) SOUZA, José Tadeu Batista. Emmanuel Lévinas: O Homem e a Obra. Revista Simposium. Ano 3, Número especial, Junho. 1999. p. 45-53.

20) WALDOW, V R. Cogitando sobre o cuidado humano. Cogitare Enferm. 1998. +(392):7-10. 